\title{
Root age influences failure location in grass species during mechanical testing
}

\author{
David Boldrin $(\mathbb{D} \cdot$ Anthony Glyn Bengough $\cdot$ Zijian \\ Lin • Kenneth Wilhelmus Loades
}

Received: 14 July 2020 / Accepted: 25 December 2020 / Published online: 30 January 2021

(C) The Author(s) 2021

\begin{abstract}
Aims Root tensile tests are often rejected if failure location is outside the middle section of samples. This study aims to identify where and why failure occurs along a root axis, and hence to revisit current approaches to testvalidity.

Methods Roots from Festuca arundinacea; Lolium multiflorum; Lolium perenne were sampled from fieldgrown plants. Roots were tensile tested using a universal testing machine. Root samples were randomly allocated into two groups for testing. Group 1 roots were orientated with the older tissue closest to the top clamp, group 2 roots were orientated oppositely. Tensile strength, Young's modulus and failure location were recorded for each sample.

Results Lolium multiflorum roots were thinner and stronger than roots of Festuca arundinacea. Failure location in tensile tests depended significantly on tissue age with $75 \%$ of samples failing in the younger third of root tissue regardless of the root orientation in the testing frame. Only $7 \%$ of roots failed in the middle third of the sample.

Conclusions Fibrous roots tested in tension were observed to consistently fail in the younger tissue along
\end{abstract}

Responsible Editor: Alexia Stokes.

D. Boldrin · A. G. Bengough · Z. Lin

School of Science and Engineering, University of Dundee,

Dundee DD1 4HN, UK

D. Boldrin $(\varangle) \cdot$ A. G. Bengough $\cdot$ K. W. Loades

The James Hutton Institute, Invergowrie, Dundee DD2 5DA, UK e-mail: d.z.boldrin@dundee.ac.uk the root axis. Exclusion of samples which fail outside the middle region of the root axis needs re-evaluation for a range of species.

Keywords Biomechanical properties · Ecoengineering · Failure location · Mechanical testing $\cdot$ Root age $\cdot$ Root clamping $\cdot$ Soil bioengineering $\cdot$ Tensile strength $\cdot$ Young's modulus

\section{Introduction}

Root biomechanical properties are fundamental parameters to understand and quantify root mechanical reinforcement provided by vegetation to soil on slopes (Giadrossich et al. 2017; Liang et al. 2017; Mao et al. 2012; Stokes et al. 2009). Tensile strength and Young's modulus are the most common biomechanical properties tested in bioengineering literature and are important inputs for predictive models of root mechanical reinforcement (Mao et al. 2012; Pollen and Simon 2005; Schwarz et al. 2013; Wu et al. 1979). In particular, root tensile strength has been reported for almost all species studied in soil bioengineering literature (Bischetti et al. 2005; De Baets et al. 2008; Mao et al. 2012; Mattia et al. 2005).

Tensile strength and Young's modulus for roots with diameter between 0.1 and $7.0 \mathrm{~mm}$ are generally obtained by laboratory tensile testing, where a root segment is clamped at either end with tensile displacement until breakage occurs (Boldrin et al. 2017; De Baets et al. 2008; Giadrossich et al. 2017; Loades et al. 2013). 
Tensile tests are generally performed using universal testing machines allowing the accurate recording of load and displacement (Boldrin et al. 2017; Hales et al. 2013; Mao et al. 2018). However, simple measurement techniques based on dead-load systems (Dumlao et al. 2015) or spring scale (Hales et al. 2013) have also been used. Mechanical properties of large diameter roots (e.g., > $7 \mathrm{~mm}$ ) are typically obtained by field pull-out tests. Roots are exposed adjacent to the parent tree through a trench and pulled out of soil (Giadrossich et al. 2017). For instance, Giadrossich et al. (2020) combined laboratory tensile tests (root diameters: $1-4 \mathrm{~mm}$ ) and field pull-out tests (root diameters: 5-57 $\mathrm{mm}$ ) to quantify mechanical properties of Pinus radiata roots.

Test results can be affected by several factors related to sample preparation and test set up (Giadrossich et al. 2017), such as sample storage (Hales et al. 2013), root moisture (Boldrin et al. 2018; Zhang et al. 2019) and extension rate (Cofie and Koolen 2001). An important issue during root tensile testing is the method of root clamping (i.e., attaching the root to the testing systems) (Giadrossich et al. 2017). Several clamp types have been used to limit slippage, root damage and provide consistent confining pressure. For example, Dumlao et al. (2015) used a simple binder clip with foam and sandpaper to attach Avena fatua roots to a dead-load system (i.e., plastic bottle filled with water). Recently, pneumatic clamps, with pressure ranging from 100 to $250 \mathrm{kPa}$ were used to control confining pressure during tensile testing of woody roots (Boldrin et al. 2017; Boldrin et al. 2018). Different solutions have also been suggested to minimise root tissue damage in clamps aimed at minimising clamp induced breakage, such as the use of epoxy around the root extremities (Tosi 2007). However, prescribed protocols for root clamping are missing and it remains difficult to ensure that the sample failure is due to tensile stress and not weakening induced by the clamping technique used.

Assessing the success of individual root tensile tests has often been related to the failure location along the root axis. Yang et al. (2016) rejected all tests in which roots failed inside or very near to the clamps. Several studies have considered the test as being successful only when the sample failed in the middle third of the root length between clamps (Bischetti et al. 2005; Genet et al. 2005, 2008, 2010; Ji et al. 2012; Mao et al. 2018; Vergani et al. 2012, 2014, 2016). In Ji et al. (2012), this resulted in a success rate lower than $50 \%$. Bischetti et al. (2005) and Vergani et al. (2016) rejected all samples that did not fail near the middle of the sample length between clamps. These approaches of assessing the validity of tensile tests have not been corroborated by previous experimental evidence about the physical mechanisms behind the failure location along the tested sample. For instance, a study by Hales et al. (2013) on Picea sitchensis roots found no strength difference between roots failing at clamps and those failing in the middle third of the sample. Therefore, Hales et al. (2013) included all samples in their analyses. To our knowledge this is the only study where failure location has been analysed in terms of biomechanical properties to assess the validity of tests.

Considering only samples failing in the middle third of root length may lead to the discard of many valid tests, increasing effort and possibly biasing the assessment of root biomechanical properties. Moreover, these approaches have been mainly suggested for woody roots which are typically stronger than roots of herbaceous plants (Bischetti et al. 2005).

The objective of this study is to assess the effect of root-tissue age on failure location along root axis in grasses. To date, approaches typically assume a valid test is one where failure along the root axis occurs in the middle third of the sample's length. We hypothesize that, when testing fibrous roots, failure location along the sample length between clamps will depend on the age of root tissues locally. The present study tests this hypothesis using fibrous roots of three different grass species.

\section{Materials and methods}

Plant material

Three common grass species (Family: Poaceae) were selected for testing in this study: Festuca arundinacea (Common name: Tall Fescue), Lolium multiflorum (Common name: Italian Ryegrass) and Lolium perenne (Common name: Perennial Ryegrass). These grass species are widespread in European pastures and listed as potential "ecological engineer" plants for soil reinforcement and protection in Norris et al. (2008). In particular, L. perenne rooted soil (root area ratio: $0.06 \%$ ) showed $154 \%$ greater shear strength than fallow soil (Comino et al. 2010).

In spring 2019, roots of each grass species were sampled from monospecific plots in Bungalow field at 
The James Hutton Institute, Dundee (UK; latitude $56^{\circ} 27^{\prime} 26^{\prime \prime} \mathrm{N}$, longitude $3^{\circ} 4^{\prime} 17^{\prime \prime} \mathrm{W}$ ). The roots were carefully sampled from the top $25 \mathrm{~cm}$ of soil with the entire root system excavated. Root systems were washed from soil using tap water over a set of sieves with mesh apertures from 2 to $0.5 \mathrm{~mm}$. Samples of straight roots (50-100 $\mathrm{mm}$ in length) were excised from the root system with labels applied to the top older region of the root. All lateral roots were removed using dissecting scissors. Damaged roots were discarded. Before biomechanical testing, root samples were stored in moist blotting tissues at $5{ }^{\circ} \mathrm{C}$ for a maximum period of $48 \mathrm{~h}$.

\section{Biomechanical testing}

All root samples were mechanically tested using a universal testing machine (Instron 5966, Norwood, MA, USA), with a $500 \mathrm{~N}$ load cell $( \pm 0.25 \%)$ and an extension rate of $2 \mathrm{~mm} \mathrm{~min}^{-1}$. Root diameter was measured at three locations along each root sample using a microscope and graticule prior to tensile testing. It should be noted that tested roots showed no evident tapering (i.e., fibrous roots, no secondary radial growth with aging). Pneumatic clamps (Instron 2712-041), set to produce a confining pressure of $100 \mathrm{kPa}$, were used to ensure a consistent clamping pressure between samples and avoid slippage of sample (Suppl.Fig. 1). This pressure was selected after a pilot experiment to identify the confining pressure to stop slippage of fibrous roots (data not shown). In the case of any slippage, tensile test was discarded. Sample length between clamps was equal to $35 \mathrm{~mm}$. Root samples were randomly allocated into two groups in terms of sample orientation in the testing frame. Group 1 roots were orientated with the older tissue closest to the top clamp (i.e., orientation I), group 2 roots were orientated oppositely (i.e., orientation II, with older tissue closest to the lower clamp). Failure location was recorded for each sample as the distance from the top clamp. Failures in the younger, middle and older tissue of the root sample were defined by dividing the root length between clamps $(35 \mathrm{~mm})$ in three equally long regions $(11.7 \mathrm{~mm})$. For example, for roots in orientation I group a failure within $11.7 \mathrm{~mm}$ from the top clamp was classified as occurring in the older tissue. Therefore, this study focused on the relative root age along a root axis excised from an intact root system. It is difficult to age root tissues or associate the length of a root section to an elongation time because the elongation rate of roots depends on several environmental conditions experienced by plants during growth (Bengough et al. 2011; Watt et al. 2003; Watt et al. 2006).

Tensile strength $(\mathrm{MPa})$ at maximum load and Young's modulus ( $\mathrm{MPa}$ ) were obtained from the stress-strain curve of the tested sample (Loades et al. 2013). The tensile strength $\left(T_{r}\right)$ at maximum load was calculated using Eq. (1).

$$
T_{\mathrm{r}}=\frac{F}{\pi\left(\frac{d^{2}}{4}\right)}
$$

where $F$ is the maximum force required to break the root $(\mathrm{N})$ and $d$ the root diameter ( $\mathrm{mm})$. Young 's modulus $\left(E_{r}\right)$ was calculated (Eq. 2) from the initial slope of the stress-strain curve within the elastic region (i.e., initial linear region):

$$
E_{\mathrm{r}}=\frac{F L_{o}}{\pi\left(\frac{d^{2}}{4}\right) \Delta L}
$$

where $F$ is the applied force $(\mathrm{N})$; Lo is the initial length (mm) of the root sample; and $\Delta L$ is the change in root length $(\mathrm{mm})$ during tensioning. Root extension at maximum load (mm) was also recorded for each sample.

\section{Statistical analysis}

The statistical analysis was performed using GenStat 17th Edition (VSN International, Hemel Hempstead, UK), RStudio (R-version 3.6.2; R Foundation for Statistical Computing, Vienna, Austria) and SigmaPlot14 (Systat Software, San Jose, CA). Significant differences between species in terms of maximum force were assessed with ANCOVA with root diameter as covariate. Tensile strength and Young's modulus were tested using one way-ANOVA, followed by post hoc Tukey's test. Tensile strength and Young's modulus data were respectively $\log$ and square root transformed before ANOVA tests. Binomial and Chi-square tests for goodness of fit were used to test for significant differences in breaking locations between younger and older portions of the root sample. The independence of breaking location (i.e., younger or older portion) from root testing orientation (i.e., orientation I and II) has been tested using Chi-square tests for independence. For each species, 40 root samples were tested considering two 
orientations ( $n$ per orientation $=20$ ). The variability in the averaged result is presented as \pm standard error of mean. The results were considered statistically significant when $p$ value $\leq 0.05$. Details (e.g., $n$ and $p$-values) of statistical analysis for each dataset are given in the text and in figure captions.

\section{Results}

Maximum force recorded during tensioning did not significantly differ between species or orientations, when tested using ANCOVA with root diameter as covariate ( $p$-values $>0.05 ; n$ per species $=40, n$ per orientation $=20$; Fig. 1a). In contrast, root tensile strength (log transformed) and Young's modulus (square root transformed) highlighted significant differences between species ( $p$-values $<0.001 ; n=40$ ), with L. multiflorum showing the largest strength $(9.91 \pm$ 1.17 MPa, max. 38.97 MPa) and Young's modulus (74.61 $\pm 9.76 \mathrm{MPa}$, max. 307.25 MPa; Fig. 1 and Table 1). In contrast, $F$. arundinacea showed significantly weaker roots $(3.86 \pm 0.31 \mathrm{MPa}$; Fig. $1 \mathrm{~b} ; p$ value $<$ 0.001; Log transformed data; $n=40)$. L. perenne highlighted intermediate biomechanical properties between $F$. arundinacea and $L$. multiflorum. While L. multiflorum $(9.91 \pm 1.17 \mathrm{MPa})$ and L. perenne $(7.92 \pm 0.46 \mathrm{MPa})$ roots showed similar tensile strength values, $L$. multiflorum roots $(74.61 \pm 9.76 \mathrm{MPa})$ had larger Young's modulus than $L$. perenne $(39.61 \pm$ $2.15 \mathrm{MPa})$. The extension at maximum load did not differ ( $p$ value $=0.06 ; n=40$ ) between the three species, averaging $10.36 \pm 0.18 \mathrm{~mm}(=0.30 \mathrm{~mm} / \mathrm{mm}$ tensile strain; data not shown). In all species, the sample orientation between clamps (i.e., older tissues close to top or bottom clamp) did not affect the test results for both tensile strength $(p$-values $=0.97(\mathrm{Fa} ; n=20) ; 0.22(\mathrm{Lm}$; $n=20) ; 0.12(\mathrm{Lp} ; n=20))$ and Young's modulus ( $p$ values $=0.65(\mathrm{Fa} ; n=20) ; 0.75(\mathrm{Lm} ; n=20) ; 0.94(\mathrm{Lp}$; $n=20)$; Fig. $1 \mathrm{~b}$ and c).

Between all the samples tested ( 3 species; 120 samples), on average $74 \pm 4 \%$ of roots failed in the youngest third of the root, with just $18 \pm 3 \%$ failing in the oldest third of the root (Figs. 2 and 3). Root failure was significantly affected by the age of the tissue (Binomial and Chi-square tests for goodness of fit for each species; $p$-values $<0.001 ; n$ per species $=40)$. In all tested species, failure location was independent (Chi-square test for independence; $p$-values $>0.05 ; \mathrm{n}$ per orientation $=$
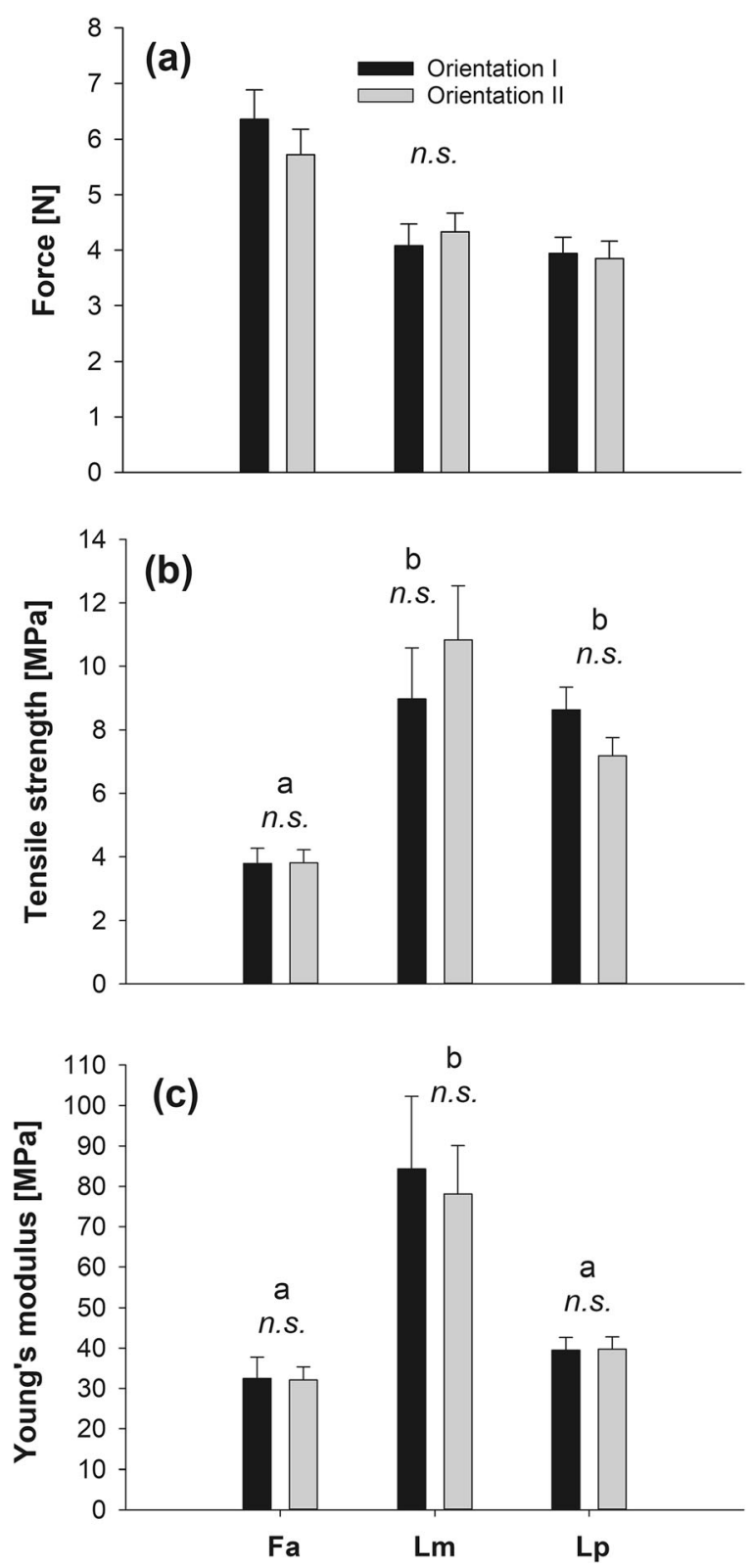

Fig. 1 Average a maximum force during tensioning, $\mathbf{b}$ tensile strength and $\mathbf{c}$ Young's modulus for the tested species: Festuca arundinacea $(\mathrm{Fa})$, Lolium multiflorum (Lm) and Lolium perenne (Lp). Orientation I (black vertical bars): older root portion closest to the top clamp; Orientation II (grey vertical bars): younger root portion closest to the top clamp. Error bars represent the standard error of mean. Force data (a) were statistically tested using ANCOVA with root diameter as covariate. $n . s$. in a indicates a lack of statistical difference ( $p$-values $>0.05$ ) between both orientations and species. Tensile strength (b) and Young's modulus (c) data were respectively log and square root transformed prior statistical analysis. $n . s$. (in $\mathbf{b}$ and $\mathbf{c}$ ) indicates no significant difference between roots tested with orientation I and II (b: p-values: 0.97 (Fa), $0.22(\mathrm{Lm}), 0.12(\mathrm{Lp})$; $\mathbf{c}:$ values: 0.65 (Fa); $0.75(\mathrm{Lm}) ; 0.94(\mathrm{Lp})$ ). Differences between species were assessed after merging data from both orientations. Different letters indicate significant differences between species, as tested by one-way ANOVA ( $p$-values $<0.001$ ) followed by post hoc Tukey's test 
20) from the root orientation between clamps (Orientation I: older tissue closest to the top clamp; Orientation II: younger tissue closest to the top clamp). Most root samples consistently failed in the younger portion irrespective of this region being at either the top or bottom clamp (Fig. 2). Indeed, while there was a significant difference between where roots failed as a distance from the top clamp based on whether roots were orientated with the older tissue at the top or bottom (One-way ANOVA; $p$ value $<0.001$; all species; $n=120$ ), there was no significant difference in root failure between species based on the distance from the older tissue end. For instance, while in $F$. arundinacea roots tested using orientation I (older tissues closest to top clamp), $75 \%$ of roots (15 samples) failed in the bottom third of sample length (i.e., closer to lower clamp), the opposite was observed in orientation II (younger tissue closest to top clamp), where $90 \%$ of roots (18 samples) failed in the top third of the sample's length (Fig. $2 \mathrm{a}$ and b). Only 22 roots on the 120 tested samples (i.e., 18\%) failed in the older third of the sample's length (Fig. 2).

Figure 3 highlights the proportion (\%) of root samples failing in the younger, middle and older regions (11.7 $\mathrm{mm}$ each) of the tested samples for F. arundinacea, L. multiflorum and L. perenne. When all species and orientations are considered, roots failing in the middle third of the sample's length (between 11.7 and $23.3 \mathrm{~mm}$ along the root axis) represented between 0 (F. arundinacea in Fig. 3b) and 15\% (L. multiflorum in Fig. 3a) of the tested roots. On the contrary, root samples failing in the younger region accounted between 65 (L. multiflorum in Fig. 3a) and 90\% (F. arundinacea in Fig. 3b) of the tested roots. Therefore, failure location along the root sample was strongly affected by tissue age in all tested species (Chi-square for goodness of fit: p-values $<0.001)$.

The relationships between root diameter and biomechanical properties (force; tensile strength; Young's modulus) are presented in Fig. 4 and Table 1. Figure 5 replots data from Figs. 2 and 4 to show root biomechanical properties in relation to failure location. In $F$. arundinacea, we observed only one sample failing in the middle portion, with a relatively small strength (2.75 MPa; Figs. 4 and 5) and the smallest Young's modulus value (11.43 MPa; Table 1). While in L. multiflorum, samples failing in the middle portion were generally weak (including weakest root: $1.48 \mathrm{MPa}$ ) and within the first quartile of strength data (5.09 $\mathrm{MPa})$, L. perenne samples failing in the middle portion were stronger than the median value $(7.56 \mathrm{MPa})$ and characterized by small diameters (< $0.8 \mathrm{~mm}$; Fig. 4). However, it should be noted that there was no clear relation between failure location and biomechanical properties (Fig. 5), and the small number of samples failing in the middle portion did not allow a comprehensive statistical analysis. The extension at failure showed no relation with failure location, as well as similar values between species $(\approx$ from $4 \mathrm{~mm}$ $(0.1$ strain $)$ to $15 \mathrm{~mm}$ (0.4 strain); data not shown).

\section{Discussion}

Our study on fibrous roots highlighted that failure location in tensile tests significantly depends on tissue age, with most of samples $(75 \pm 4 \%)$ failing in the younger third of root sample, regardless of sample orientation between clamps. In contrast, failures in the middle third were rare $(7 \pm 2 \%)$.

\section{Biomechanical properties of the tested species}

Tested grasses did not significantly differ in terms of maximum force during tensioning when root diameter was used as covariate. Significant differences in terms of biomechanical properties, with L. multiflorum showing the largest strength (38.97 MPa) and Young's modulus (307.25 MPa), can thus be explained by the root diameter differences in tested species. In general, roots of the tested species can be considered relatively weak if compared to literature data on fibrous roots for different grass species (Comino et al. 2010; De Baets et al. 2008). While in our study, L. perenne showed a maximum strength value of $15.60 \mathrm{MPa}$ in a $0.63 \mathrm{~mm}$ diameter root, Comino et al. (2010) reported tensile strength values up to $365.29 \mathrm{MPa}$ in a $0.10 \mathrm{~mm}$ diameter root of L. perenne. However, this can be explained by the different diameter ranges tested in the present study and in the literature. While in the present study no root thinner than $0.45 \mathrm{~mm}$ was tested, Comino et al. (2010) tested roots in a diameter range between 0.1 and $0.7 \mathrm{~mm}$. When the same diameter is considered, our strength results agree with literature data. Indeed, it is worth highlighting that extreme strength values (e.g., > $200 \mathrm{MPa}$ ) in the biomechanical properties of different grass species found in the literature, were generally 
measured in fine roots, with a diameter smaller than $0.2 \mathrm{~mm}$ (De Baets et al. 2008; Comino et al. 2010). The smaller tensile strength of $F$. arundinacea roots, in respect to Lolium species, may be due to its thicker cortex (assessed by visual inspection of samples). Cortex, consisting of parenchymal tissue with fine cell walls, is generally weaker compared with the stele (Chimungu et al. 2015). A thicker cortex can lead to smaller tensile strength, as the overall root diameter (cortex and stele) is used to calculate tensile strength and Young's modulus, rather than the dimensions of the tissue conferring most tensile strength (stele) (Chimungu et al. 2015; Hathaway and Penny 1975). Previous literature has highlighted the large variability of root anatomy between grass species, genotypes and environmental conditions (Baruch and Mérida 1995; Chimungu et al. 2015; Soper 1959; Vanhees et al. 2020). For example, among the tested species, roots of Lolium perenne with $0.56 \pm 0.03 \mathrm{~mm}$ average diameter have $0.23 \pm 0.01$ stele-diameter and $0.16 \pm 0.01 \mathrm{~mm}$ cortical thickness (Soper 1959). Chimungu et al. (2015) investigated the root biomechanical properties of twenty-six maize genotypes (Zea mays; Poaceae) with stele diameter and cortical thickness ranging between 0.4 to $1.1 \mathrm{~mm}$ and between 0.3 and $0.6 \mathrm{~mm}$, respectively. While, tensile strength was strongly associated to stele diameter, root bend strength was associated with cortical thickness. Both these anatomical parameters were better predictors of biomechanical properties (under tensioning and bending) than root diameter.

Young's modulus notably differed between the tested species. While having similar tensile strength, Lolium species showed a significant difference in terms of Young's modulus (Fig. 1). Despite the root Young's modulus controlling the capacity of the root to deform during the soil mass movement, and hence root reinforcement activation, Young's modulus data are severely lacking in the literature on root biomechanical properties, which mainly focus on root tensile strength. In particular, few studies tested the Youngs's modulus of fibrous roots (Dumlao et al. 2015; Loades et al. 2013; Mahannopkul and Jotisankasa 2019). Both tensile strength and Young's modulus decreased with increasing diameter and were fitted by a negative power model
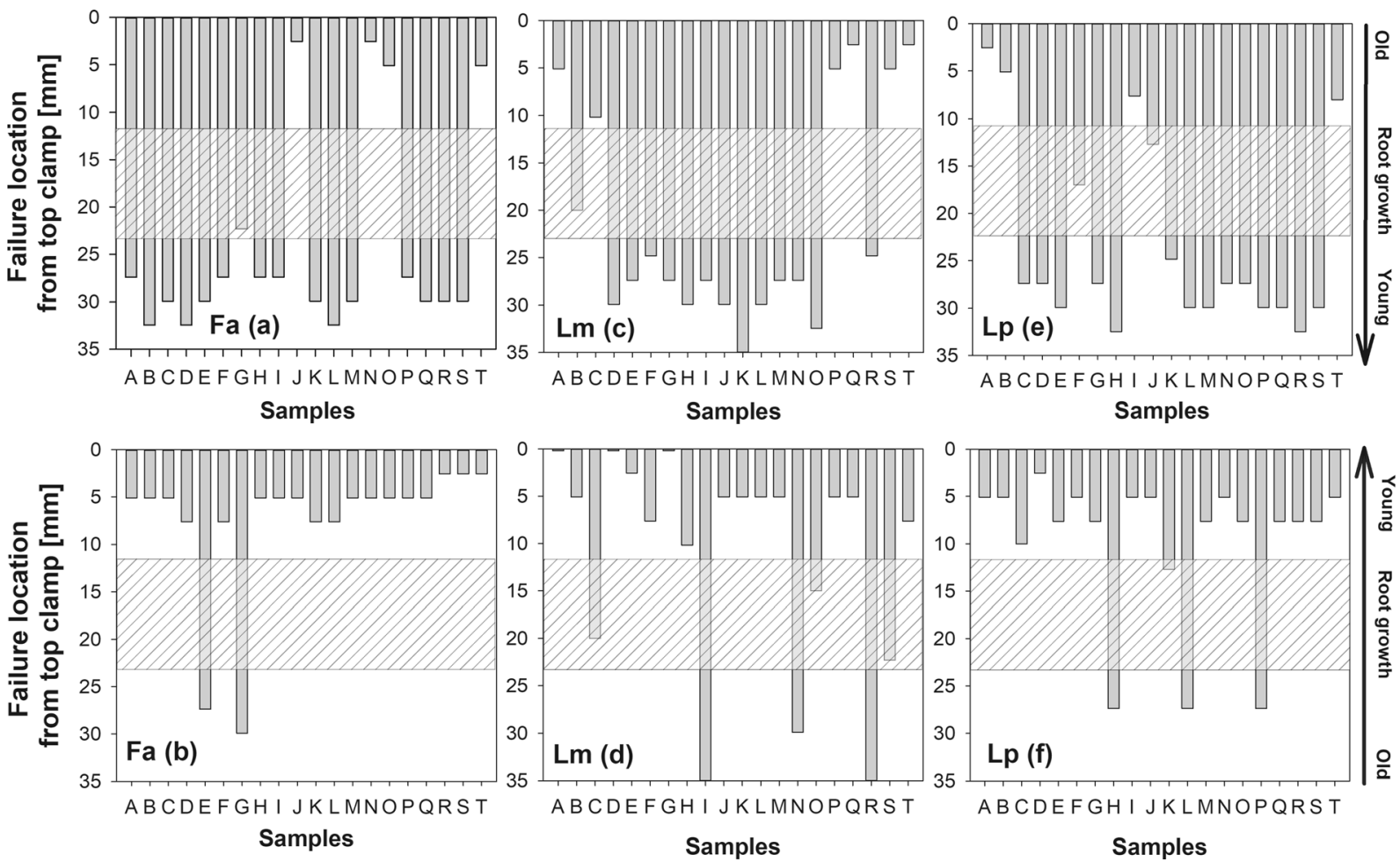

Fig. 2 Distance between top clamp and failure location for the 20 root samples (letters from A to T) of Festuca arundinacea. (Fa; a and b), Lolium multiflorum (Lm; c and d) and Lolium perenne (Lp; e and f) for Orientation I (a, c and e): older tissue closest to the top

clamp and Orientation II (b, $\mathbf{d}$ and $\mathbf{f})$ : younger tissue closest to the top clamp. Root length between clamps: $35 \mathrm{~mm}$. The area (oblique line pattern) in the graphs represents the middle third of the sample's length (i.e., between 11.7 and $23.3 \mathrm{~mm}$ ) 


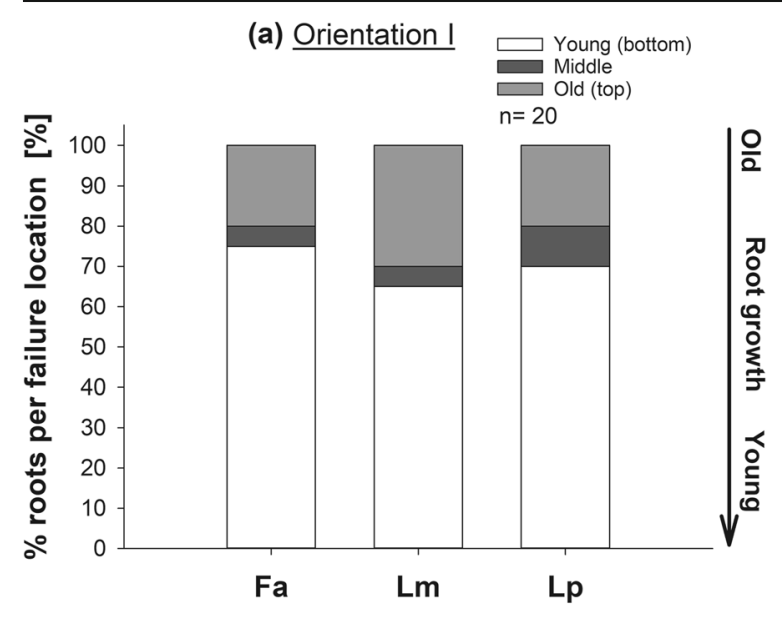

(b) Orientation II

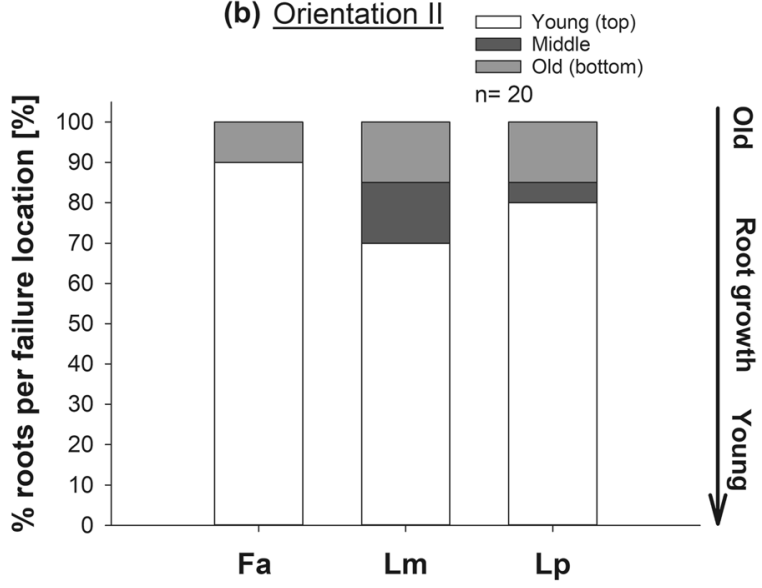

Fig. 3 Percentage of roots failing in the young, middle and old portions of the tested root samples $(n=20)$. a Orientation I: older tissue closest to the top clamp; b Orientation II: younger tissue closest to the top clamp. Root length between clamps was $35 \mathrm{~mm}$. Each root portion (i.e., young, middle and old) account for $11.7 \mathrm{~mm}(=35 / 3)$ of the root section

(Fig. 4; Table 1), in accordance with literature on fibrous roots (Comino et al. 2010; De Baets et al. 2008; Dumlao et al. 2015; Loades et al. 2013). However, the explanatory strength of these negative power relations (i.e., $\mathrm{R}^{2}$; Table 1) varied between species. Although, root tensile strength has been generally assumed to follow a negative power-law relation in literature (Mao et al. 2012), the strength of these relationships can vary greatly (e.g., $\mathrm{R}^{2}$ from $<0.05$ to $>0.80$ ) between species, growing environments and testing conditions (Bischetti et al. 2005; Boldrin et al. 2018; Ghestem et al. 2014; Loades et al. 2013; Mahannopkul and Jotisankasa 2019). In soil bioengineering literature, this negative power relation, where strength increases with decreasing diameter, has been explained with cellulose and lignin content (Genet et al. 2005; Zhang et al. 2014); root moisture (Boldrin et al. 2018), root anatomy (Chimungu et al. 2015) and autocorrelation, as tensile strength is calculated using diameter (Hales et al. 2009). Therefore, there is no clear agreement on the drivers of the diameter-strength relation and its use to highlight root mechanical properties. Moreover, diameter variability in fine roots can translate to large differences in the computed biomechanical properties. Supplementary Fig. 2 (replot of Fig. 4d-f) is given to highlight the variability and uncertainty of tensile strength due to root diameter variability along the tested root axis. In this study, we show the commonly reported relation between diameter and both tensile strength and Young's modulus to facilitate comparison with other studies in the literature.

Failure location during tensile testing

Failure location in tensile tests significantly depends on tissue age with most of samples $(75 \pm 4 \%)$ failing in the youngest third of the root sample regardless of root orientation in the testing frame. On the contrary, only $18 \pm 3$ and $7 \pm 2 \%$ of root samples failed in the oldest and middle third of the sample's length between clamps $(35 \mathrm{~mm})$. Despite the variability in diameter and biomechanical properties between the tested species (Figs. 1 and 4), root failure in the youngest third was consistent between the three tested grasses (i.e., F. arundinacea: 83\%; L. multiflorum: $67 \%$; L. perenne: $75 \%$ ). This result can be explained by root strengthening with age in agreement with previous studies on Hordeum vulgare by Loades et al. (2015) and Avena fatua by Dumlao et al. (2015), where root strength increased with increasing distance from the root tip (root age proxy). The increase in root strength with increasing distance from the root tip (i.e., root age) has been explained with cellulose content and the lignin deposition during tissue development, as these organic polymers are the main structural components involved in tissue strength (Genet et al. 2005; Niklas 1992; Zhang et al. 2014). Loades et al. (2015) found that root age (i.e., distance from the root tip) was the best predictor of root biomechanical properties and suggested that models for root mechanical reinforcement and anchorage can be improved by including root age among the input parameters. The present study is based on the relative root age along a root axis. Indeed, it is difficult to determine root age or 

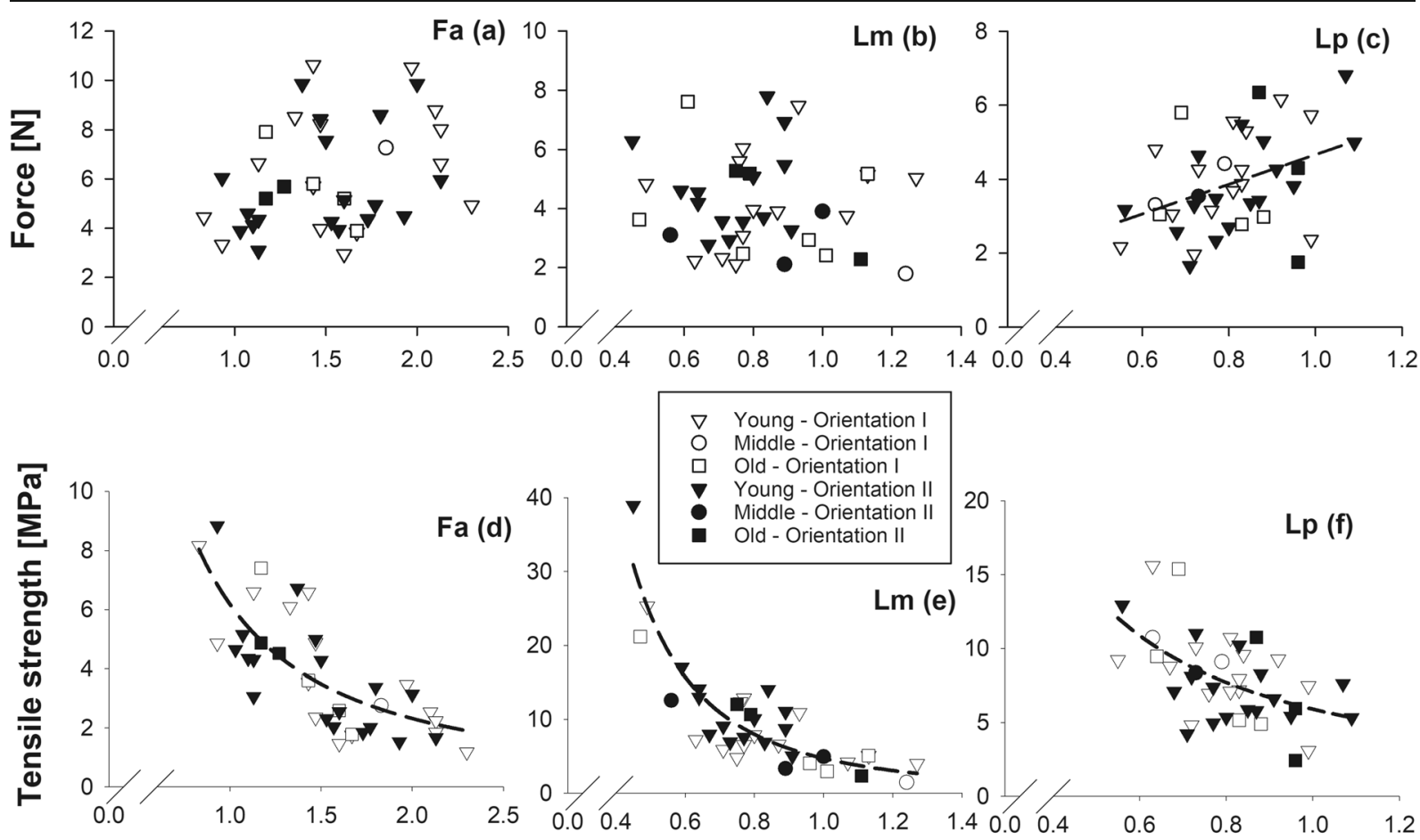

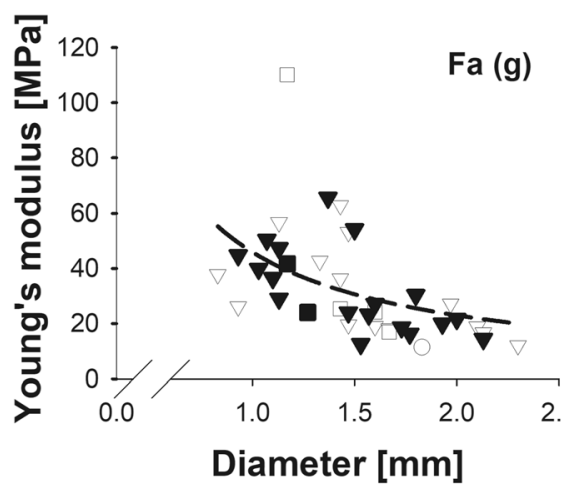

Fig. 4 Root diameter plotted against maximum force during tensioning $(\mathbf{a} ; \mathbf{b} ; \mathbf{c})$, tensile strength at maximum load $(\mathbf{d} ; \mathbf{e} ; \mathbf{f})$ and Young's modulus $(\mathbf{g} ; \mathbf{h} ; \mathbf{i})$ for roots failing in the younger $(\boldsymbol{\nabla})$, middle $(\bullet)$ and older $(\boldsymbol{\bullet})$ portions for both orientation I (open symbols) and orientation II (closed symbols). Acronyms: Fa:

age differences along the root axis. Under optimal conditions, primary root axes of grasses show elongation rates of 15-70 $\mathrm{mm} \mathrm{d}^{-1}$ (e.g., wheat and barley (Cohen and Tadmor 1969; Gregory 2008)). However, elongation rate depends on species, plant age, root type, season, soil depth, temperature, mechanical impedance (e.g., soil compaction) and soil moisture (Bengough et al. 2011; Cohen and Tadmor 1969; Garwood 1967; Watt et al. 2003; Watt et al. 2006). Roots grow 1.5 times faster when plants are young and generally the branch roots have slower elongation compared with seminal roots (Watt et al. 2006). Moreover, although shootborne grass roots are mainly produced in autumn and early spring, root elongation is faster during summer (Garwood 1967). This seasonal variation on root elongation can be explained by the direct effect of environmental temperature on root development (Pahlavanian and Silk 1988). Mechanical impedance (i.e., soil 


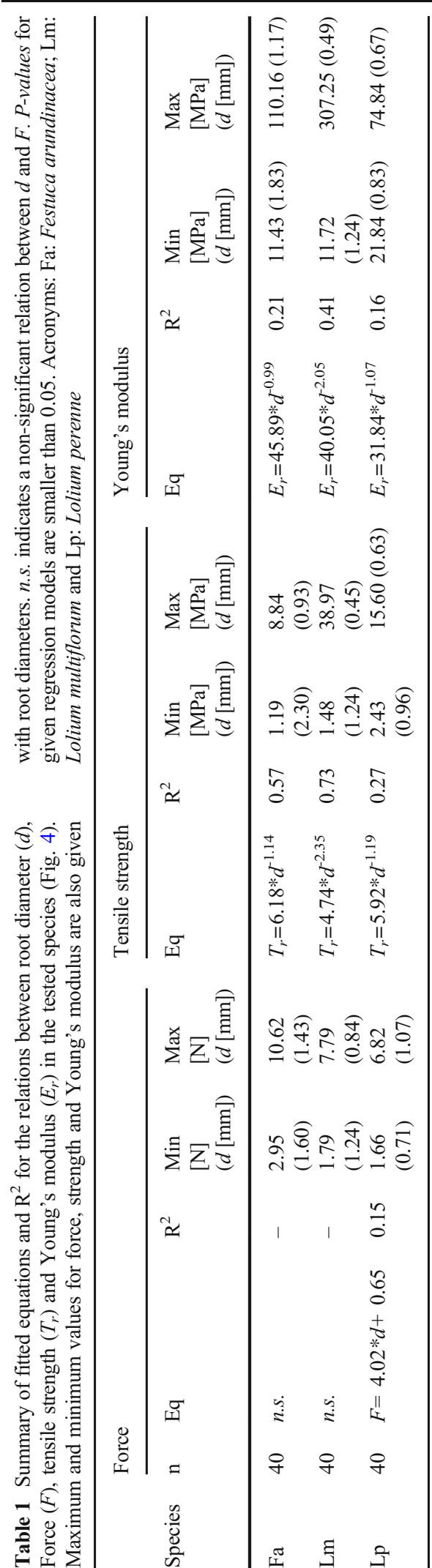

penetration resistance) and water stress are major limiting factors to root elongation. Root elongation is generally halved when penetrometer resistance exceeds 0.8 $2 \mathrm{MPa}$ (in well-watered conditions; Bengough et al. (2011)). For example, Watt et al. (2003) reported a drop of elongation rate of wheat (Triticum aestivum) roots from $24.5 \mathrm{~mm} \mathrm{~d}^{-1}$ in loose soil to $8.16 \mathrm{~mm} \mathrm{~d}-1$ in hard soil. Moreover, in drying soils, where growth is generally constrained by a combination of mechanical and water stress, root elongation can also drop by $>40 \%$ compared with roots in well-watered conditions (e.g., Avena fatua roots in Dumlao et al. (2015)). Loades et al. (2015) highlighted the influence of mechanical impedance and waterlogging (i.e., constraints of root growth) on the relation between root age, diameter and biomechanical properties. For instance, the relation between biomechanical properties (tensile strength and Young's modulus) and both diameter and age became more scattered when roots, subjected to waterlogging, were tested. Furthermore, while woody roots show secondary radial growth (i.e., root thickening) with aging, fibrous roots of grasses show less evident change of root anatomy with aging.

Failures in the middle third of the root axis were rare. For instance, root samples failing in the middle third accounted between 3 and $10 \%$ of the tested samples for $F$. arundinacea and L. multiflorum, respectively. Therefore, assessing the success of root tensile tests based on the failure location along the root axis, with roots failing in the middle third being successful tests as suggested for woody roots (Bischetti et al. 2005; Genet et al. 2005, 2008, 2010; Ji et al. 2012; Mao et al. 2018; Vergani et al. 2012,2014 ; 2016), would lead to the rejection of most tests for fibrous roots, with a consequent increase in cost and efforts. For example, considering the observed proportion of samples failing in the middle third, we would need to test more than 500 samples to obtain 40 valid tensile tests, which is the typical number of samples used to assess biomechanical properties of a species (Boldrin et al. 2018; Mao et al. 2018). Moreover, there is a risk of bias in results of biomechanical studies analysing only biomechanical properties of rare, and non-representative samples failing in the middle, while excluding the common and biophysically-sound failures in the youngest third of the root axis (Figs. 2 and 3). For instance, while $F$. arundinacea and L. multiflorum samples failing in the middle region were generally weak (including weakest root: $1.48 \mathrm{MPa}$ of L. multiflorum), 

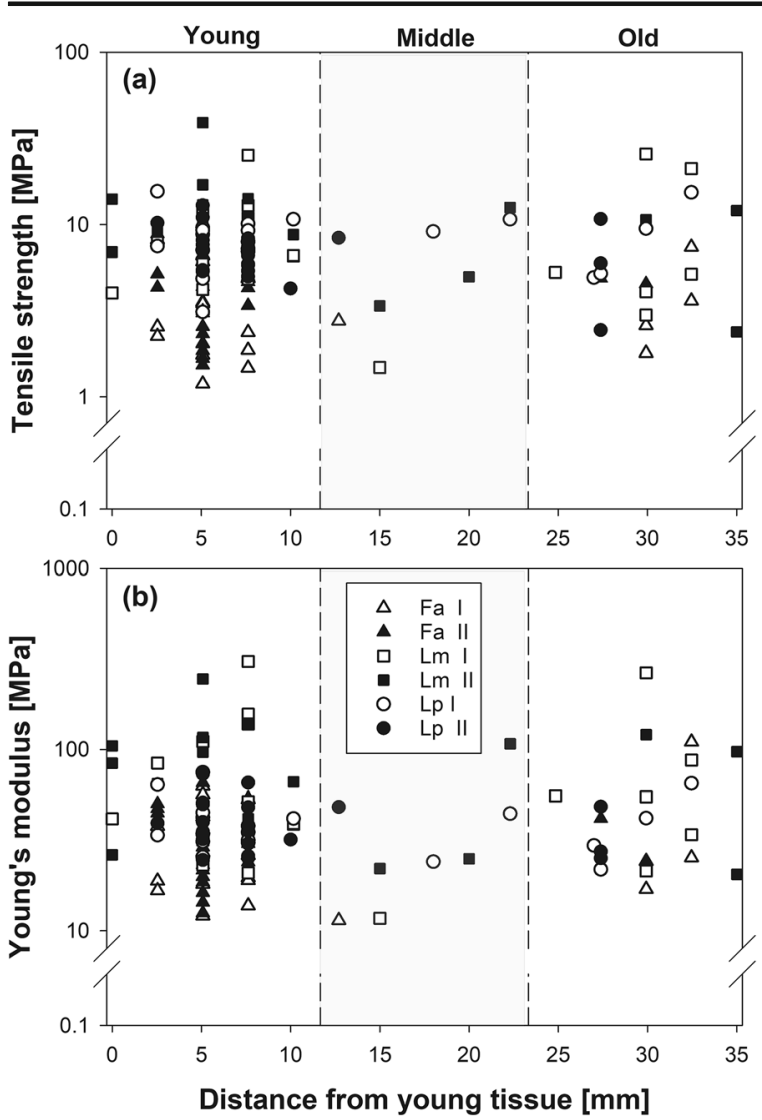

Fig. 5 Root tensile strength (a) and Young's modulus (b) plotted against the distance from the young tissue (i.e., younger extremity in clamp) for the three tested species, and both orientation I (open symbols) and orientation II (close symbols). Acronyms: Fa: Festuca arundinacea (\); Lm: Lolium multiflorum (-) and Lp: Lolium perenne $(\bullet)$. The grey area between dashed lines represents the middle third of the sample's length (i.e., between 11.7 and $23.3 \mathrm{~mm}$ ). Y-axis are given in logarithmic scale

L. perenne samples failing in the middle region were stronger than the median value (7.56 MPa; Figs. 4 and 5). Dried and re-hydrated roots of tree species, which are generally stronger than fresh roots, showed a higher proportion of failures in the middle third of the sample in a study by Hales et al. (2013). However, in the present study, the small number of roots failing in the middle portion did not allow a fair comparison with roots failing in the younger and older portions. On the other hand, roots failing on top and bottom thirds (i.e., closer to the clamp edges) were not weaker than roots failing in the middle third, despite potential effects of confining pressure imposed by clamps (Fig. 5). Therefore, we did not find any evidence of direct weakening induced by clamping. It should be noted that failure locations along root axis were defined by dividing the initial (i.e., before testing) root length between clamps $(35 \mathrm{~mm})$ in three equally long regions $(11.7 \mathrm{~mm})$, thus assuming no change in sample length after tensile testing and breakage. We recognize the limit of this assumption and potential for small changes in sample length due to plastic strain and failure. Changes in sample length or tissue deformation after tensioning were not measured in the present study. Although root extension during testing was recorded, this cannot be used to estimate sample length after failure because of elastic-plastic behaviour of roots, heterogeneous strain along root axis (e.g., in young and old tissues), as well as potential contractions of root tissues after failure. Therefore, further work is needed to investigate root plastic strain in relation to failure location along a root axis.

This methodological study provides novel evidence for assessing the success of root tensile tests of fibrous roots in soil bioengineering. Root biomechanical properties are fundamental parameters to understand, quantify and predict root mechanical reinforcement provided by vegetation to soil on slopes, and hence design proper mitigation solutions in area prone to shallow landslides (Mao et al. 2012). Therefore, prediction of root derived mechanical reinforcement relies on robustness of empirical data and their quality control. For protocols aimed at testing fibrous roots, we need to re-evaluate the exclusion of root samples which fail out with the middle region of the root axis as this appears poorly justified, with failure occurring typically in the youngest region along the root axis and no clear biomechanical differences between roots failing in the top, middle or bottom third along the sample axis between clamps (Fig. 5). This study also reinforces earlier findings by Loades et al. (2015) and Dumlao et al. (2015), with root age representing one of the main drivers of biomechanical properties for fibrous roots. For example, roots of Avena fatua increased in strength from $28 \mathrm{MPa}$ to $42 \mathrm{MPa}$ as distance from the root tip increased from $24 \mathrm{~cm}$ to $29 \mathrm{~cm}$ (Dumlao et al. 2015) - root diameter did not vary in this region. This would presumably mean that a $5 \mathrm{~cm}$ root sample from this region of tissue would record a tensile strength of $28 \mathrm{MPa}$ with failure occurring in the youngest tissue. The root would not be expected to fail in the middle or upper half of the root until the stress reached $35 \mathrm{MPa}$. Given that failure of any material sample should be determined by the weakest part of that sample, adoption of the mid-zone region for being the only accepted region for recording sample failures may risk introducing systematic bias into the measurement of 
root strength. For soil stabilisation on slopes, the smaller strength of younger roots may imply that for a given root area ratio, root reinforcement provided by grasses can be weaker in soil volume newly explored by roots (e.g., decrease of root strength down soil profile). This should be considered when soil bioengineering techniques are applied for stabilisation and ecological restoration of landscapes where vegetation cover had been removed by landslides or industrial activities (Chaulya et al. 2000). Indeed, both root spread in soil and root aging may be necessary to fully achieve the reinforcement potential of pioneering species.

Our findings showed that tissue age is the main driver of failure in tensile tests of grass roots. An interaction between root age and clamps cannot be excluded, where the effect of clamp confining pressure is greater on younger tissues respect to older tissues. For instance, the relatively greater number $(18 \%)$ of roots failing in the older third compared to failures in the middle third (7\%) may imply a potential effect of clamping. However, clamping was of lesser importance compared with tissue age. Further work is necessary to quantify potential tissue weakening due to clamping in respect to root age and type (e.g., fibrous or woody).

\section{Conclusions}

Fibrous roots tested in tension were observed to consistently fail in the younger tissue along the root axis. In contrast, roots failing in the middle region of the sample accounted for less than $10 \%$ of the tested samples. We propose that the exclusion of root samples which fail out with the middle region of the root samples during tensile testing is poorly justified, with failure occurring typically in the youngest region along the root axis. Our findings were based on tensile testing of fibrous roots without secondary radial growth. Future work is necessary to understand failure location along the root axis of woody roots which are characterized by secondary growth resulting in possible root tapering along the root axis, different anatomy and chemical composition. The degree of tapering will depend on the root section length used to assess root mechanical properties. Although cortex tissues generally fail before ultimate failure, and it has been suggested that stele tissues are main drivers of tensile strength in both fibrous and woody roots (Chimungu et al. 2015; Hathaway and Penny 1975), future work is necessary to understand the relation between root anatomy and biomechanical properties in contrasting grass species. Further research is also needed to investigate potential interactions between tissue age and clamping (e.g., weakening due to confining pressure).

Supplementary Information The online version contains supplementary material available at https://doi.org/10.1007/s11104020-04824-6.

Acknowledgements This work was partly funded by the Rural \& Environment Science \& Analytical Services Division of the Scottish Government. A. G. Bengough and D. Boldrin were funded by the EPSRC project (EP/R005834/1) "Climate Adaptation Control Technologies for Urban Spaces (CACTUS)" and EPSRC (EP/M020355/1). Zijian Lin acknowledges funding from Hunan University for his time at the University of Dundee. Authors thank the anonymous referees for helpful discussions and advice.

Open Access This article is licensed under a Creative Commons Attribution 4.0 International License, which permits use, sharing, adaptation, distribution and reproduction in any medium or format, as long as you give appropriate credit to the original author(s) and the source, provide a link to the Creative Commons licence, and indicate if changes were made. The images or other third party material in this article are included in the article's Creative Commons licence, unless indicated otherwise in a credit line to the material. If material is not included in the article's Creative Commons licence and your intended use is not permitted by statutory regulation or exceeds the permitted use, you will need to obtain permission directly from the copyright holder. To view a copy of this licence, visit http://creativecommons.org/licenses/by/4.0/.

\section{References}

Baruch Z, Mérida T (1995) Effects of drought and flooding on root anatomy in four tropical forage grasses. Int J Plant Sci 156: 514-521. https://doi.org/10.1086/297274

Bengough AG, McKenzie BM, Hallett PD, Valentine TA (2011) Root elongation, water stress, and mechanical impedance: a review of limiting stresses and beneficial root tip traits. J Exp Bot 62:59-68. https://doi.org/10.1093/jxb/erq350

Bischetti GB, Chiaradia EA, Simonato T, Speziali B, Vitali B, Vullo P, Zocco A (2005) Root strength and root area ratio of forest species in Lombardy (Northern Italy). Plant Soil 278: 11-22. https://doi.org/10.1007/s11104-005-0605-4

Boldrin D, Leung AK, Bengough AG (2017) Root biomechanical properties during establishment of woody perennials. Ecol Eng 109:196-206. https://doi.org/10.1016/j. ecoleng.2017.05.002 
Boldrin D, Leung AK, Bengough AG (2018) Effects of root dehydration on biomechanical properties of woody roots of Ulex europaeus. Plant Soil 431:347-369. https://doi. org/10.1007/s11104-018-3766-7

Chaulya SK, Singh RS, Chakraborty MK, Srivastava BK (2000) Quantification of stability improvement of a dump through biological reclamation. Geotech Geol Eng 18:193-207. https://doi.org/10.1023/A:1026576711324

Chimungu JG, Loades KW, Lynch JP (2015) Root anatomical phenes predict root penetration ability and biomechanical properties in maize (Zea mays). J Exp Bot 66:3151-3162. https://doi.org/10.1093/jxb/erv121

Cofie P, Koolen AJ (2001) Test speed and other factors affecting the measurements of tree root properties used in soil reinforcement models. Soil Tillage Res 63:51-56. https://doi. org/10.1016/S0167-1987(01)00225-2

Cohen Y, Tadmor NH (1969) Effects of temperature on the elongation of seedling roots of some grasses and legume1. Crop Science 9: cropsci1969.0011183X000900020024x. https://doi.org/10.2135/cropsci 1969.0011183 X000900020024x

Comino E, Marengo P, Rolli V (2010) Root reinforcement effect of different grass species: A comparison between experimental and models results. Soil Tillage Res 110:60-68. https://doi.org/10.1016/j.still.2010.06.006

De Baets S, Poesen J, Reubens B, Wemans K, De Baerdemaeker J, Muys B (2008) Root tensile strength and root distribution of typical Mediterranean plant species and their contribution to soil shear strength. Plant Soil 305:207-226. https://doi. org/10.1007/s11104-008-9553-0

Dumlao MR, Ramananarivo S, Goyal V, DeJong JT, Waller J, Silk WK (2015) The role of root development of Avena fatua in conferring soil strength. Am J Bot 102:1050-1060. https://doi.org/10.3732/ajb.1500028

Garwood EA (1967) Seasonal variation in appearance and growth of grass roots. Grass Forage Sci 22:121-130. https://doi. org/10.1111/j.1365-2494.1967.tb00514.x

Genet M, Stokes A, Salin F, Mickovski SB, Fourcaud T, Dumail JF, Van Beek R (2005) The influence of cellulose content on tensile strength in tree roots. Plant Soil 278:1-9. https://doi. org/10.1007/s11104-005-8768-6

Genet M, Kokutse N, Stokes A, Fourcaud T, Cai X, Ji J, Mickovski S (2008) Root reinforcement in plantations of Cryptomeria japonica D. Don: effect of tree age and stand structure on slope stability. For Ecol Manag 256:1517-1526. https://doi.org/10.1016/j.foreco.2008.05.050

Genet M, Stokes A, Fourcaud T, Norris JE (2010) The influence of plant diversity on slope stability in a moist evergreen deciduous forest. Ecol Eng 36:265-275. https://doi.org/10.1016/j. ecoleng.2009.05.018

Ghestem M, Cao K, Ma W, Rowe N, Leclerc R, Gadenne C, Stokes A (2014) A framework for identifying plant species to be used as 'ecological engineers' for fixing soil on unstable slopes. PLoS One 9. https://doi.org/10.1371/journal. pone. 0095876

Giadrossich F, Schwarz M, Cohen D, Cislaghi A, Vergani C, Hubble T, Phillips C, Stokes A (2017) Methods to measure the mechanical behaviour of tree roots: a review. Ecol Eng 109:256-271. https://doi.org/10.1016/j.ecoleng.2017.08.032

Giadrossich F, Schwarz M, Marden M, Marrosu R, Phillips C (2020) Minimum representative root distribution sampling for calculating slope stability in Pinus radiata d.Don plantations in New Zealand. N Z J For Sci 50:1-12. https://doi. org/10.33494/nzjfs502020x68x

Gregory PJ (2008) Plant Roots: Growth, Activity and Interactions with the Soil. Wiley-Blackwell, Oxford

Hales TC, Ford CR, Hwang T, Vose JM, Band LE (2009) Topographic and ecologic controls on root reinforcement. J Geophys Res Solid Earth 114. https://doi.org/10.1029/2008 JF001168

Hales TC, Cole-Hawthorne C, Lovell L, Evans SL (2013) Assessing the accuracy of simple field based root strength measurements. Plant Soil 372:553-565. https://doi. org/10.1007/s11104-013-1765-2

Hathaway RL, Penny D (1975) Root strength in some populus and salix clones. N Z J Bot 13:333-344. https://doi.org/10.1080 /0028825X.1975.10430330

Ji J, Kokutse N, Genet M, Fourcaud T, Zhang Z (2012) Effect of spatial variation of tree root characteristics on slope stability. A case study on Black Locust (Robinia pseudoacacia) and Arborvitae (Platycladus orientalis) stands on the Loess Plateau, China. Catena 92:139-154. https://doi.org/10.1016 j.catena.2011.12.008

Liang T, Bengough AG, Knappett JA, MuirWood D, Loades KW, Hallett PD, Boldrin D, Leung AK, Meijer GJ (2017) Scaling of the reinforcement of soil slopes by living plants in a geotechnical centrifuge. Ecol Eng. https://doi.org/10.1016/j. ecoleng.2017.06.067

Loades KW, Bengough AG, Bransby MF, Hallett PD (2013) Biomechanics of nodal, seminal and lateral roots of barley: Effects of diameter, waterlogging and mechanical impedance. Plant Soil 370:407-418. https://doi.org/10.1007 /s11104-013-1643-y

Loades KW, Bengough AG, Bransby MF, Hallett PD (2015) Effect of root age on the biomechanics of seminal and nodal roots of barley (Hordeum vulgare L.) in contrasting soil environments. Plant Soil (1-9). https://doi.org/10.1007 /s11104-015-2560-z

Mahannopkul K, Jotisankasa A (2019) Influence of root suction on tensile strength of Chrysopogon zizanioides roots and its implication on bioslope stabilization. J Mt Sci 16:275-284. https://doi.org/10.1007/s11629-018-5134-8

Mao Z, Saint-André L, Genet M, Mine FX, Jourdan C, Rey H, Courbaud B, Stokes A (2012) Engineering ecological protection against landslides in diverse mountain forests: choosing cohesion models. Ecol Eng 45:55-69. https://doi. org/10.1016/j.ecoleng.2011.03.026

Mao Z, Wang Y, McCormack ML, Rowe N, Deng X, Yang X, Xia S, Nespoulous J, Sidle RC, Guo D, Stokes A (2018) Mechanical traits of fine roots as a function of topology and anatomy. Annals of Botany: mcy076-mcy076. https://doi. org/10.1093/aob/mcy076

Mattia C, Bischetti GB, Gentile F (2005) Biotechnical characteristics of root systems of typical Mediterranean species. Plant Soil 278:23-32. https://doi.org/10.1007/s11104-005-7930-5

Niklas KJ (1992) Plant Biomechanics: An Engineering Approach to Plant Form and Function. University of Chicago Press, Chicago

Norris JE, Di Iorio A, Stokes A, Nicoll BC, Achim A (2008) Species selection for soil reinforcement and protection. In: Slope stability and erosion control: ecotechnological 
solutions. pp 167-210. https://doi.org/10.1007/978-1-40206676-4-6

Pahlavanian AM, Silk WK (1988) Effect of Temperature on Spatial and Temporal Aspects of Growth in the Primary Maize Root. Plant Physiol 87:529. https://doi.org/10.1104 /pp.87.2.529

Pollen N, Simon A (2005) Estimating the mechanical effects of riparian vegetation on stream bank stability using a fiber bundle model. Water Resour Res 41:1-11. https://doi. org/10.1029/2004WR003801

Schwarz M, Giadrossich F, Cohen D (2013) Modeling root reinforcement using a root-failure Weibull survival function. Hydrol Earth Syst Sci 17:4367-4377. https://doi. org/10.5194/hess-17-4367-2013

Soper K (1959) Root anatomy of grasses and clovers. N Z J Agric Res 2:329-341.https://doi.org/10.1080 /00288233.1959.10420321

Stokes A, Atger C, Bengough AG, Fourcaud T, Sidle RC (2009) Desirable Plant root traits for protecting natural and engineered slopes against landslides. Plant Soil 324:1-30. https://doi.org/10.1007/s11104-009-0159-y

Tosi M (2007) Root tensile strength relationships and their slope stability implications of three shrub species in the Northern Apennines (Italy). Geomorphology 87:268-283. https://doi. org/10.1016/j.geomorph.2006.09.019

Vanhees DJ, Loades KW, Bengough AG, Mooney SJ, Lynch JP (2020) Root anatomical traits contribute to deeper rooting of maize under compacted field conditions. J Exp Bot 71:42434257. https://doi.org/10.1093/jxb/eraa165

Vergani C, Chiaradia EA, Bischetti GB (2012) Variability in the tensile resistance of roots in Alpine forest tree species. Ecol Eng 46:43-56. https://doi.org/10.1016/j. ecoleng.2012.04.036

Vergani C, Chiaradia EA, Bassanelli C, Bischetti GB (2014) Root strength and density decay after felling in a Silver Fir-
Norway Spruce stand in the Italian Alps. Plant Soil 377:6381. https://doi.org/10.1007/s11104-013-1860-4

Vergani C, Schwarz M, Soldati M, Corda A, Giadrossich F, Chiaradia EA, Morando P, Bassanelli C (2016) Root reinforcement dynamics in subalpine spruce forests following timber harvest: a case study in Canton Schwyz, Switzerland. Catena 143:275-288. https://doi.org/10.1016/j. catena.2016.03.038

Watt M, McCully ME, Kirkegaard JA (2003) Soil strength and rate of root elongation alter the accumulation of Pseudomonas spp. and other bacteria in the rhizosphere of wheat. Funct Plant Biol 30:483-491. https://doi.org/10.1071 /FP03045

Watt M, Silk WK, Passioura JB (2006) Rates of root and organism growth, soil conditions, and temporal and spatial development of the rhizosphere. Ann Bot 97:839-855. https://doi. org/10.1093/aob/mcl028

Wu TH, McKinnell Iii WP, Swanston DN (1979) Strength of tree roots and landslides on price of Wales Island, Alaska. Can Geotech J 16:19-33

Yang Y, Chen L, Li N, Zhang Q (2016) Effect of root moisture content and diameter on root tensile properties. PLoS One 11: e0151791. https://doi.org/10.1371/journal.pone.0151791

Zhang C-B, Chen L-H, Jiang J (2014) Why fine tree roots are stronger than thicker roots: the role of cellulose and lignin in relation to slope stability. Geomorphology 206:196-202. https://oi.org/10.1016/j.geomorph.2013.09.024

Zhang C, Zhou X, Jiang J, Wei Y, Ma J, Hallett PD (2019) Root moisture content influence on root tensile tests of herbaceous plants. CATENA 172:140-147. https://doi.org/10.1016/j. catena.2018.08.012

Publisher's note Springer Nature remains neutral with regard to jurisdictional claims in published maps and institutional affiliations. 